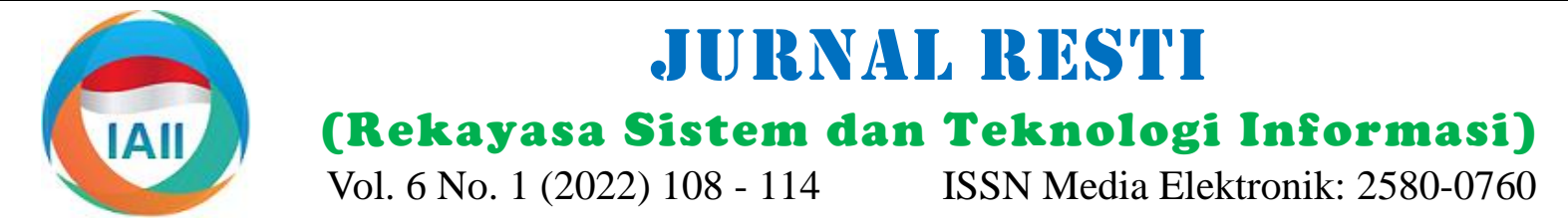

\title{
Analisis Spasial Untuk Klasifikasi Pengembangan Tempat Penampungan Sementara Menggunakan Metode Jaringan Syaraf Tiruan
}

\author{
Luqman Hakim ${ }^{1}$, Anik Vega Vitianingsih², Gita Indah Marthasari ${ }^{3}$, \\ Kresna Arief Nugraha ${ }^{4}$, Anastasia Lidya Maukar ${ }^{5}$ \\ ${ }^{1,3}$ Informatika, Teknik, Universitas Muhammadiyah Malang \\ ${ }^{2,4}$ Teknik Informatika, Teknik, Universitas Dr. Soetomo \\ ${ }^{5}$ Teknik Industri, Teknik, President University \\ 11luqman.hakim@umm.ac.id*, ${ }^{2}$ vega@unitomo.ac.id, ${ }^{3}$ gita@umm.ac.id, \\ ${ }^{4}$ kresnaarief541@gmail.com, ${ }^{5}$ almaukar@ president.ac.id
}

\begin{abstract}
Garbage is a problem that needs an in-depth study in urban areas because the development of an area has consequences on increasing population density, facilities and infrastructure, public services, and other aspects that impact increasing the volume of waste. The distribution of temporary waste shelters (TPS) in each area is still insufficient to accommodate the volume of waste, and its availability is inadequate. The purpose of this study is to model spatial data through spatial analysis using artificial intelligence methods in classifying the development of integrated temporary shelter locations (TPST) and regional integrated temporary shelters (TPST Regions) by utilizing Web-based technology (Geographical Information System (WebGIS). The Artificial Neural Network method with the Backpropagation algorithm is used for the spatial analysis process based on the parameters of the population, the amount of organic and inorganic waste, the amount of industrial waste, and the volume of the TPST and Regional TPST capacity. The spatial analysis results using the Artificial Neural Network method obtained an accuracy value of $7171.02 \%$. The results of this study can be the basis for Department of Environment and Cleanliness policies for the development of TPST and TPST areas with information coverage at the village level.
\end{abstract}

Keywords: Spatial Analysis, Web-GIS, Garbage Shelters, Artificial Neural Network, Backpropagation.

\begin{abstract}
Abstrak
Permasalahan sampah memerlukan perhatian serius akhir-akhir ini. Perkembangan daerah seiring dengan meningkatknya kepadatan penduduk, sarana dan prasarana, pelayanan publik, dan aspek lainnya serta berdampak pula pada peningkatan volume sampah. Persebaran tempat penampungan sementara (TPS) sampah yang disediakan di setiap daerah tidak sebanding dengan pertambahan volume sampah. Tujuan penelitian ini adalah untuk melakukan pemodelan data spasial melalui analisis spasial menggunakan metode kecerdasan buatan dalam mengklasifikasikan pengembangan lokasi penampungan sementara terpadu (TPST) dan tempat penampungan sementara terpadu kawasan (TPST Kawasan) dengan memanfaatkan teknologi SIG (Sistem Informasi Geografis) berbasis Web (Web-GIS). Metode Jaringan Syaraf Tiruan dengan algoritma Backpropagation digunakan dalam proses analisis spasial berdasarkan parameter jumlah penduduk, jumlah sampah penduduk organik dan anorganik, jumlah sampah industri, serta volume daya tampung TPST dan TPST Kawasan. Hasil analisis spasial dengan metode Jaringan Syaraf Tiruan memperoleh nilai akurasi 7171,02 \%. Hasil penelitian ini dapat menjadi dasar kebijakan Dinas Lingkungan Hidup dan Kebersihan (DLHK) untuk pengembangan lokasi TPST dan TPST Kawasan dengan cakupan informasi pada level kelurahan atau desa.
\end{abstract}

Kata kunci: Analisis Spasial, Web-GIS, Tempat Penampungan Sampah, Jaringan Syaraf Tiruan, Backpropagation.

\section{Pendahuluan}

Perkembangan suatu daerah yang semakin meningkat beriringan dengan peningkatannya, baik dari padatnya penduduk, prasarana, pelayanan publik, serta aspek lainnya sehingga mampu berdampak pada permasalahan sampah. Berdasarkan peraturan UU-RI No.18 Tahun 2008 tentang Pengolahan Sampah, telah dijelaskan bahwa pengelolaan sampah sejauh ini masih belum sesuai dengan metode dan teknik pengelolaan sampah yang berwawasan lingkungan, sehingga dapat menimbulkan dampak negatif terhadap kesehatan

Diterima Redaksi: 16-12-2021 | Selesai Revisi: 24-02-2022 | Diterbitkan Online: 27-02-2022 
masyarakat dan lingkungan [1]. Pertambahan jumlah penduduk, perubahan pola dan peningkatan konsumsi masyarakat, serta aktivitas kehidupan masyarakat, dapat menimbulkan peningkatan volume dan jenis sampah, serta karakteristik sampah yang semakin beragam [2]. Estimasi volume sampah dapat diketahui dengan metode pengambilan data secara sampling berdasarkan dengan parameter kepadatan penduduk dan estimasi volume sampah, menghasilkan estimasi volume sampah dari angka kepadatan penduduk [3].

Sampah yang telah ditimbulkan akan menjadi permasalahan lingkungan yang wajib ditangani oleh pemerintah kota setempat. Langkah pemerintah dalam mengatasi permasalahan sampah, akan dibantu dengan dukungan partisipasi masyarakat.

Kategori pengelolaan sampah terdiri dari tempat penampungan sementara (TPS), diantaranya tempat penampungan sementara terpadu (TPST) dan tempat penampungan sementara terpadu kawasan (TPST Kawasan). Data Statistik dari Dinas Lingkungan Hidup Jawa Timur 2017, Kabupaten Sidoarjo menempati posisi ketiga dari total kabupaten/kota yang ada, dengan mencapai lebih dari $1.000 .000 / \mathrm{kg}$ sampah tiap harinya [2]. Data Statistika Lingkungan Hidup 2017 [2] dengan volume sampah di Sidoarjo masih cukup tinggi. Persebaran TPST dan TPST Kawasan yang telah disediakan masih kurang memadai ketersediannya, sehingga perlu pengembangan TPS baru. Pembahasan paper ini mengambil studi kasus untuk pengembangan TPS Dinas Lingkungan Hidup dan Kebersihan (DLHK) Kabupaten Sidoarjo.

Berdasarkan permasalahan tersebut, maka pada pembahasan paper ini dilakukan Analisis spasial untuk klasifikasi pengembangan tempat penampungan sementara menggunakan metode jaringan syaraf tiruan (JST) berbasis Web-GIS. Analisis spasial merupakan teknik bidang Sistem Informasi Geografis (SIG) untuk membuat pemodelan dari data heterogen yang dihasilkan [4]. Pemodelan data spasial dalam analisis spasial SIG mendukung analisis kuantitatif untuk menghasilkan pengambilan keputusan dengan merepresentasikan data spasial dan data atribut [5]. Metode kecerdasan buatan banyak digunakan untuk melakukan proses Analisis spasial berbasis multicriteria spasial decision making [6].

Pengembangan lokasi baru untuk pengembangan TPS banyak dilakukan kajian pada penelitian terdahulu, diantaranya peneltian metode buffer berdasarkan parameter penggunaan lahan, hidrologi bawah tanah, geologi, jaringan jalan dan kegiatan penduduk, menghasilkan terdapat daerah yang cocok untuk pembangunan fasilitas pembuangan akhir terbaik [7]. Penggunakan metode binary dan pendekatan kuantitatif dalam proses buffering dan overlay layer untuk Analisis spasial pemilihan lokasi tempat pembuangan akhir (TPA) berbasis SIG, multi kriteria parameter yaitu berdasarkan penggunaan lahan, kawasan strategis, jarak terhadap permukiman, menghasilkan keluaran lokasi alternatif TPA [8].

Penelitian berikutnya menggunakan metode Technique for Order of Preference by Similarity to Ideal Solution (TOPSIS) dan OWA (Ordered Weighted Averaging) untuk SIG Analisis spasial variabel efektif terhadap kinerja layanan TPS berdasarkan parameter hasil analisis statistik variabel penyimpanan limbah, jumlah stasiun limbah, jarak perjalanan maksimum kapasitas kontainer, menghasilkan keluaran jumlah negatif stasiun sampah dan angkutan sedangkan jarak berjalan maksimum meningkatkan kinerja layanan penyimpanan limbah [9].

Metode Analytical hierachy process (AHP) dengan parameter kepadatan populasi, jarak ke pusat pembuangan, budaya pemilahan sampah, jaringan jalan, digunakan untuk SIG analisis spasial dalam pengembangan tempat pembuangan sampah [10]. Analisis spasial untuk pengembangan TPA baru yang aman atau tidak aman untuk pembangunan TPA menggunakan metode AHP berdasarkan parameter aspek kemiringan, suhu, curah hujan, zona gempa, kepadatan populasi, jarak pandang dari jalan, dan DEM [11]. Berdasarkan kajian melalui studi literatur tersebut menjadi dasar peneliti untuk memilih metode JST berdasarkan perilaku data yang akan diolah ke pemodelan data spasial berdasarkan parameter hasil kajian peneliti sebelumnya

Tujuan dari pembahasan paper ini adalah guna melakukan Analisis spasial berbasis Web-GIS untuk klasifikasi pengembangan TPST dan TPST Kawasan menggunakan metode JST dengan algoritma Backpropagation berdasarkan parameter jumlah penduduk, jumlah sampah penduduk organik, jumlah sampah an-organik, jumlah sampah industri, volume daya tampung TPST, volume daya tampung TPST Kawasan tiap kelurahan atau desa.

Paramater yang digunakan pada penelitian ini diambil dari Dinas Lingkungan Hidup dan Kebersihan di Bidang Kebersihan Kabupaten Sidoarjo dengan acuan Peraturan Daerah kabupaten sidoarjo No.6 tahun 2012 dan pedoman teknis pelaksanaan TPS 3R tempat pengolahan sampah reduce-reuse-recycle.

\section{Metode Penelitian}

Tahapan penelitian untuk klasifikasi pengembangan TPST dan TPST kawasan seperti yang terlihat pada Gambar 1. 


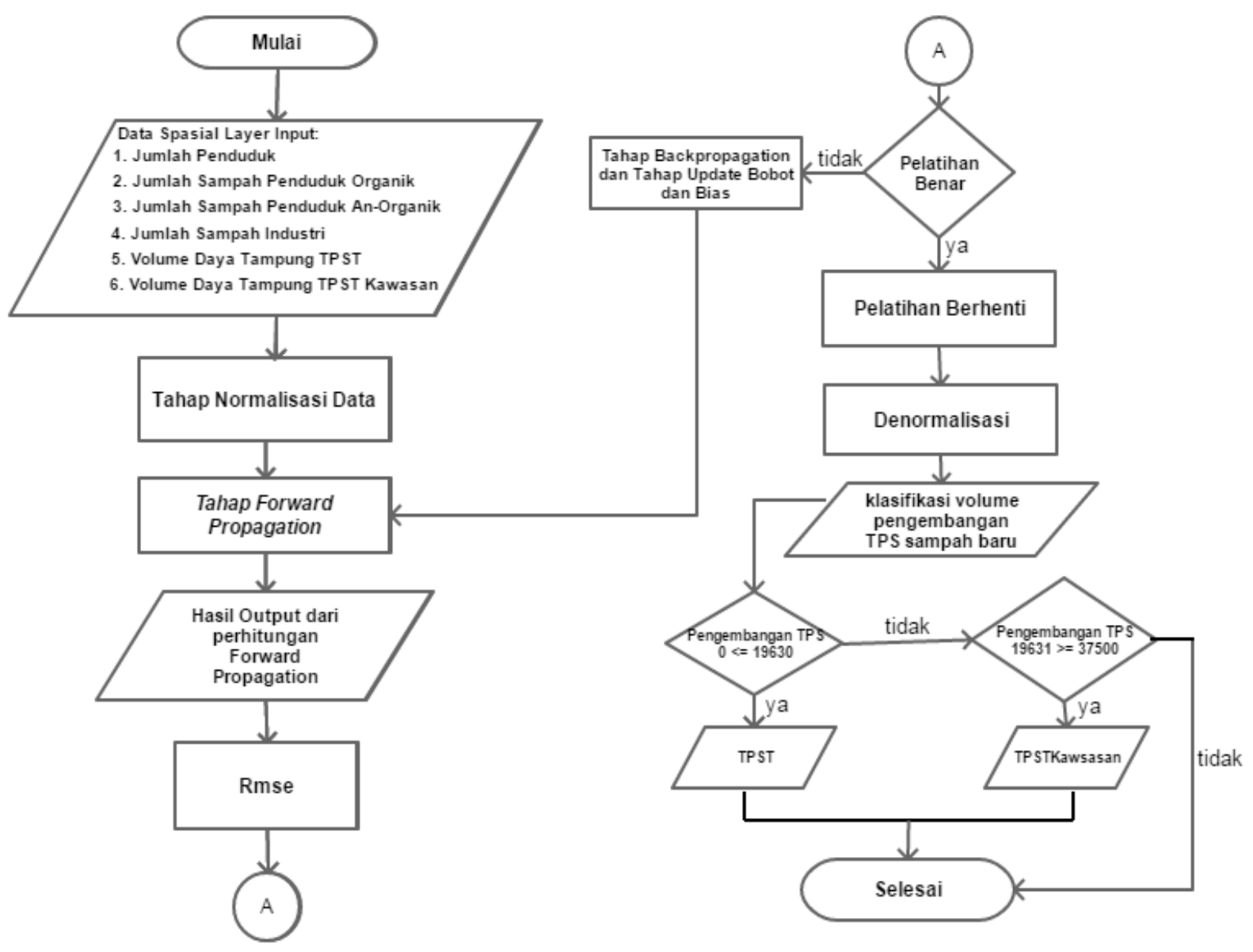

Gambar 1. Flowchart JST Algoritma Backpropogation

Langkah-langkah pada Gambar 1, yaitu:

Step 1: Identifikasi kebutuhan data spasial dan data atribut yang akan digunakan untuk pemodelan data spasial dalan SIG Analisis spasial. Pada penelitian ini menggunakan cakupan data spasial yaitu peta dasar wilayah Kabupaten Sidoarjo dengan cakupan data pada level Desa/Kelurahan.

Step 2: Proses normalisasi data input parameter untuk proses perhitungan forward propagation.

Step 3: Proses check kebenarannya menggunakan perhitungan Root Mean Square Error (RMSE) menggunakan persamaan (7), dimana:

a. Jika pelatihan data benar maka proses berhenti, jika pelatihan data tidak benar maka akan masuk ke proses tahap Backpropagation dan tahap Update bobot dan bias.

b. Jika pelatihan data tidak benar maka akan proses tahap Backpropagation dan tahap Update bobot dan bias.

Step 4: Hasil dari forward propagation di-check kebenarannya menggunakan perhitungan RMSE sampai hasil dari proses check benar. Jika pelatihan data benar akan dilakukan proses denormalisasi untuk mengembalikan data yang ternomalisasi.
Step 5: Lakukan proses de-normalisasi untuk mendapatkan hasil klasifikasi volume tampungan pengembangan TPS baru. Setelah itu lakukan dengan melihat range pengembangan TPS baru berdasarkan cakupan pada Tabel 1 [12] [Sumber: Wawancara Staff Bidang Kebersihan Dinas Lingkungan Hidup dan Kebersihan Kabupaten Sidoarjo Bapak Miftachul Ilmi, tanggal 20 Juli 2020, 12.52 WIB].

Tabel 1. Parameter Volume Daya Tampung TPST dan TPST Kawasan

\begin{tabular}{lll}
\hline Jumlah Sampah & Satuan & Keterangan \\
\hline $0 \leq 19630$ & Kilogram & \multicolumn{2}{l}{ Jika sampah total } \\
& & dengan berat \\
& & tersebut masuk \\
& & kedalam daya \\
$19631-37500$ & Kilogram & tampung TPST \\
& & Jika sampah total \\
& & dengan berat \\
& tersebut masuk \\
& & kedalam daya \\
& & Tampung TPST \\
& & Kawasan \\
\hline
\end{tabular}

\subsection{Spatial Dataset}

Spasial dataset terdiri dari dua komponen yaitu data spasial dan data atribut [13]. Dataset spasial digunakan 
untuk mengklasifikasikan parameter yang mempengaruhi proses pengembangan TPST dan TPST kawasan. Tabel 2 merupakan spatial dataset yang mmenjadi parameter untuk Analisis spasial pada penelitian ini.

Pada setiap dataset spasial diberikan nilai range, untuk menentukan batas nilai tingkat pengaruh terhadap klasifikasi pengembangan TPST dan TPST kawasan.

Tabel 2. Deskripsi parameter spasial dataset pengembangan TPS

\begin{tabular}{lll}
\hline Dataset Spatial (satuan) & Range & Keterangan \\
\hline Jumlah Penduduk (jiwa) [14] & $\leq 150$ & Rendah \\
& $151 \leq 200$ & Sedang \\
& $201 \leq 400$ & Tinggi \\
& $>400$ & Sangat Padat \\
\hline Jumlah Sampah Penduduk Organik & $200 \leq 400$ & Kecil \\
(kg) [15] & $1500 \leq 3000$ & Sedang \\
& $3000 \geq 4500$ & Besar \\
\hline Jumlah Sampah Pendurduk & $200 \leq 400$ & Kecil \\
Anorganik (kg) [15] & $1500 \leq 3000$ & Sedang \\
& $3000 \geq 4500$ & Besar \\
\hline Jumlah Sampah Industri (kg)[15] & $200 \leq 400$ & Kecil \\
& $1500 \leq 3000$ & Sedang \\
& $3000 \geq 4500$ & Besar \\
\hline
\end{tabular}

2.2. Metode Jaringan Syaraf Tiruan Algoritma Backpropogation

Langkah-langkah metode JST Algoritma Backpropagation sebagai berikut [16] yaitu:

Step 1: Inisialisasi bobot.Lakukan normalisasi data input di persamaan (1).

Nilai $X_{\text {Baru }}=\frac{\text { Nilai } X_{\text {Lama }}-\text { Nilai } X_{\text {Baru }}}{\text { Nilai } X_{\text {Maksimum }}-\text { Nilai } X_{\text {Minimum }}}$

Dimana, Nilai $X_{\text {baru }}$ adalah nilai $x$ input yang ternormalisasi, NilaiX $X_{\text {lama }}$ adalah nilai $x$ input yang belum ternormalisasi.

Step 2: Menjumlahkan sinyal-sinyal untuk ke hidden layer persamaan (2).

$\mathrm{z}_{\text {inj }}=v_{0 j}+\sum_{i=1}^{n} x_{i} v_{i j}$

Dimana $z_{-i n j}$ adalah persamaan untuk mendapatkan sinyal ke hidden layer, $\mathrm{v}_{0 \mathrm{j}}$ adalah bobot awal untuk bias ke hidden layer yaitu masukkan dari $\left(v_{01}, v_{02}, \ldots \ldots, v_{0 n}\right)$, $\mathrm{x}_{\mathrm{i}}$ adalah unit input yaitu $\left(x_{1}, x_{2}, \ldots, x_{n}\right)$, dan $v_{i j}$ adalah bobot awal input ke hidden layer yaitu masukkan nilai dari $\left(v_{1}, v_{2}, \ldots, v_{n}\right)$

Step 3: Fungsi aktivasi sigmoid binner untuk menghitung sinyal outputnya untuk ke hidden layer di persamaan (3).

$z j=f\left(\mathrm{z}_{\text {inj }}\right)$

Dimana, $z_{j}$ adalah nilai sinyal aktivasi hidden layer, $f$ adalah fungsi dari aktivasi, $z_{i n j}$ adalah nilai hasil sinyal input ke hidden layer yaitu masukkan dari $\left(z_{i n 1}, z_{i n 2}, \ldots\right.$, $z_{\text {in } n) \text {. }}$
Step 4: Hitung unit output sinyal $\left(y_{\text {ink }}\right)$ dengan menjumlahkan bobot sinyal input hidden layer menggunakan persamaan (4).

$y_{i n_{k}}=w 0_{k}+\sum_{i=0}^{p} z_{j} w_{j k}$

Dimana, $y_{\text {ink }}$ adalah unit output untuk menjumlahkan bobot sinyal ouput, $w O_{k}$ adalah bobot awal bias ke output layer, $z_{j}$ adalah nilai hasil perhitungan nilai aktivasi hidden layer, $w_{j k}$ adalah bobot awal hidden layer ke ouput layer yaitu masukkan dari $\left(w_{1}, w_{2}, \ldots\right.$, $\left.w_{n}\right)$.

Step 5: Fungsi aktivasi untuk menghitung sinyal ouputnya di persamaan (5).

$y_{k}=f\left(y_{\text {ink }}\right)$

Dimana, $y_{k}$ adalah nilai sinyal aktivasi, $f$ adalah fungsi aktivasi, $y_{\text {ink }}$ adalah nilai hidden layer ke output layer.

Step 6: Check error dan hasil dari check error di kuadratkan persamaan (6).

$y-y_{k}$ dan kuadrat error $=(E)^{2}$

Dimana, $E$ adalah perhitungan check error, $y$ adalah nilai output target awal, $y_{k}$ adalah nilai sinyal aktivasi output.

Step 7: Menguji rata-rata error output-nya menggunakan RMSE (Root Mean Square Error) berdasarkan persamaan (7) [17].

$\operatorname{RMSE}=\sum_{i=1}^{n} \frac{(y i-y n)^{2}}{n}$

Dimana, $y_{i}$ adalah Nilai target, $y_{n}$ adalah Nilai hasil prediksi, dan $n$ adalah Jumlah data input yang diujikan berdasarkan standart RMSE pada Tabel 3 [17]. Hasil output ternormalisasi ke denormalisasi di persamaan (8).

\begin{tabular}{ll}
\multicolumn{2}{c}{ Tabel 3. Standar Error RMSE } \\
\cline { 2 - 2 } Jumlah & Keterangan \\
\hline $0,0-1,0$ & Nilai Error Benar \\
\hline
\end{tabular}

$Y n-x \min =\frac{(x o-x) \cdot(x \max -x \min )}{\operatorname{target}-x}$

Dimana, $Y_{n}$ adalah hasil sinyal output, $x_{\min }$ adalah data input $x$ terkecil, $x_{o}$ adalah hasil denormalisasi, $x$ adalah data awal, $x_{\max }$ adalah data input $x$ terbesar, $x_{\text {min }}$ adalah data input $x$ terkecil, target adalah titik acuan, dan $x$ adalah data sebelum dinormalisasi.

\subsection{Metode MAPE (Mean Absolute Percentage Error)}

Metode MAPE dimanfaatkan untuk nilai keakurasian hasil analisis dan actual [18]. Nilai MAPE memiliki 4 kategori dapat dilihat pada Tabel 4 dan persamaan (9).

MAPE $=\sum_{t=1}^{n}\left(\left(\frac{(\text { deviasi absolut })}{(\text { data } \text { aktual })}\right) / n\right) * 100$ 
Tabel 4. Nilai Kategori MAPE

\begin{tabular}{ll}
\hline Hasil MAPE & Keterangan \\
\hline$<10 \%$ & Sangat akurat \\
$10 \%-20 \%$ & Baik \\
$20 \%-50 \%$ & Wajar \\
$>50 \%$ & Kurang akurat \\
\hline
\end{tabular}

Dengan deviasi absolut adalah hasil perhitungan selisih data aktual dengan hasil prediksi, data aktual adalah data rill, dan $\mathrm{n}$ adalah jumlah data yang diujikan.

\section{Hasil dan Pembahasan}

Eksperimen hasil akan diujikan pada salah satu wilayah di Desa Tambak Kemerakan Kabupaten Sidoarjo dengan hasil pada Gambar Data parameter yang digunakan sesuai dengan Tabel 1.

Gambar 2 merupakan hasil analisis spasial berbasis Web-GIS yang mengacu pada Tabel 4 untuk klasifikasi pengembangan TPST dan TPST kawasan, titik peta dengan warna biru merupakan wilayah yang perlu pengembangan TPST dan peta dengan titik warna merah merupakan wilayah yang perlu pengembangan TPST Kawasan.

Gambar 3 merupakan informasi wilayah yang digunakan sebagai uji coba pada pembahasan paper ini dengan nilai hasil mengacu pada Tabel 5 .

Tabel 4. Hasil Klasifikasi Pengembangan TPS Menggunakan Metode

\begin{tabular}{ll}
\multicolumn{2}{c}{ JST } \\
\hline Pengembangan TPS & Jumlah \\
\hline TPST & 91 \\
TPST Kawasan & 170 \\
\hline
\end{tabular}

Tabel 5. Hasil Klasifikasi Pengembangan TPS di Desa Tambak

\begin{tabular}{ll}
\multicolumn{2}{c}{ Kemerakan } \\
\hline Pengembangan TPS & Jumlah \\
\hline TPST & 91 \\
TPST Kawasan & 170 \\
\hline
\end{tabular}

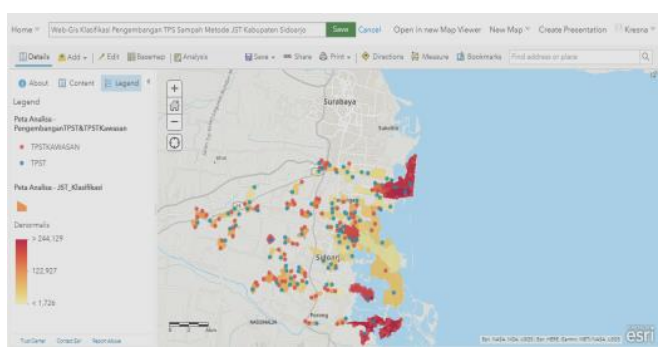

Gambar 2. Hasil Klasifikasi Pengembangan TPST dan TPST Kawasan Dengan Metode JST

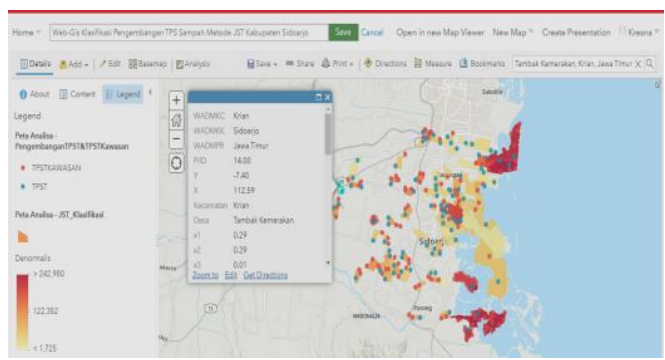

Gambar 3. Hasil Pemetaan di Desa Tambak Kemerakan
Tahapan untuk mendapatkan hasil pada Gambar 2 dan 3 yaitu:

Step 1: Lakukan inisialisasi bobot dengan memberikan inputan bobot untuk input awal ke hidden layer pada masing-masing parameter yaitu,

(v_11,v_12,v_13,v_14,v_15,v_16,v_21,v_22,v_23,v_2 $4, \mathrm{v} \_25, \mathrm{v} \_26, \mathrm{v} \_31, \mathrm{v} \_32, \mathrm{v} \_33, \mathrm{v} \_34, \mathrm{v} \_35, \mathrm{v} \_36, \mathrm{v} \_41, \mathrm{v}$ $42, \mathrm{v} \_43, \mathrm{v} \_(44,) \mathrm{v} \_45, \mathrm{v} \_46, \mathrm{v} \_51, \mathrm{v} \_52, \mathrm{v} \_53, \mathrm{v} \_54, \mathrm{v} \_5 \overline{5}$ ,v_56,v_61,v_62, v_63,v_64,v_65,v_66)

dimana, bobot untuk awal bias ke hidden layer ( $\mathrm{v} \_01$, v_02, v_03, v_04, v_05, v_06), bobot awal hidden layer ke ouput layer (w_1, w_2, w_3, w_4, w_5, w_6), dan bobot awal bias ke ouput layer (w_0).

Step 2: Lakukan normalisasi data input menggunakan persamaan (1), dimana,

$$
\begin{aligned}
& \text { Nilai } X_{1,2, . . n} \text { ternormalisasi }= \\
& \frac{\text { Nilai } X_{\text {belum normalisasi }}-\text { Nilai } X_{\text {minimum }}}{\text { Nilai } X_{\text {maximum- Nilai }} X_{\text {minimum }}}
\end{aligned}
$$

Dimana $\mathrm{X} 1$ adalah data jumlah penduduk, $\mathrm{X} 2$ adalah data jumlah sampah penduduk organic, X3 adalah jumlah sampah penduduk anorganik, X4 adalah data jumlah sampah, X5 adalah data volume daya tampung TPST, dan X6 adalah data volume data tampung TPST Kawasan.

Step 3: Lakukan penjumlahan sinyal-sinyal untuk ke hidden layer menggunakan Persamaan (2), dimana,

$$
\begin{aligned}
& \mathrm{z}_{\mathrm{in}_{1}}=v_{01}+x_{1} * v_{11}+x_{2} * v_{21}+x_{3} * v_{31}+x_{4} \\
& * v_{41}+x_{5} * v_{51}+x_{6} * v_{61} \\
& \mathrm{z}_{\mathrm{in}_{2}}=v_{02}+x_{2} * v_{12}+x_{2} * v_{22}+x_{3} * v_{32}+x_{4} \\
& * v_{42}+x_{5} * v_{52}+x_{6} * v_{62} \\
& \mathrm{z}_{\mathrm{in}_{3}}=v_{03}+x_{1} * v_{13}+x_{2} * v_{23}+x_{3} * v_{33}+x_{4} \\
& * v_{43}+x_{5} * v_{53}+x_{6} * v_{63} \\
& \mathrm{z}_{\mathrm{in}_{4}}=v_{04}+x_{1} * v_{14}+x_{2} * v_{24}+x_{3} * v_{34}+x_{4} \\
& * v_{44}+x_{5} * v_{54}+x_{6} * v_{64} \\
& \mathrm{z}_{\mathrm{in}_{5}}=v_{05}+x_{1} * v_{15}+x_{2} * v_{25}+x_{3} * v_{35}+x_{4} \\
& * v_{45}+x_{5} * v_{55}+x_{6} * v_{65} \\
& \mathrm{z}_{\mathrm{in}_{6}}=v_{06}+x_{1} * v_{16}+x_{2} * v_{26}+x_{3} * v_{36}+ \\
& x_{4} * v_{46}+x_{5} * v_{56}+x_{6} * v_{66}
\end{aligned}
$$

Step 4: Aktifasi fungsi aktivasi sigmoid binner diterapkan untuk menghitung sinyal output ke hidden layer menggunakan Persamaan (3) dengan nilai-nilai berikut,

$$
\begin{aligned}
\mathrm{z}_{1} & =\frac{1}{1+e^{- \text {zin } 1}} & \mathrm{z}_{2} & =\frac{1}{1+e^{- \text {zin } 2}} \\
\mathrm{z}_{3} & =\frac{1}{1+e^{- \text {zin } 3}} & \mathrm{z}_{4} & =\frac{1}{1+e^{- \text {zin } 4}} \\
\mathrm{z}_{5} & =\frac{1}{1+e^{- \text {zin } 5}} & \mathrm{z}_{6} & =\frac{1}{1+e^{- \text {zin } 6}}
\end{aligned}
$$

Step 5: Jumlahkan bobot sinyal input hidden layer untuk unit output akan menjadi (y_ink) menggunakan

DOI: https://doi.org/10.29207/resti.v6i1.3713

Lisensi: Creative Commons Attribution 4.0 International (CC BY 4.0) 
Persamaan (4) dengan nilai $y_{\text {ink }}$ adalah 0, 11909.

Step 6: Terapkan fungsi aktivasi untuk menghitung sinyal ouput menggunakan Persamaan (5) dengan nilai $y_{k}$ adalah 0,502977 .

Step 7: Lakukan testing error dan hasil dari check error dikuadratkan dengan menggunakan persamaan (6), yaitu,

$$
\begin{aligned}
& E=1-0.502977=0,497023 \\
& \text { kuadrat error }=(0,497023)^{2}=0,247032
\end{aligned}
$$

Step 8: Uji rata-rata rata error output-nya menggunakan RMSE berdasarkan Persamanaan (7). Jika nilai RMSE kecil maka nilai yang diprediksi dekat dengan nilai yang diamati, jika nilai RMSE besar maka nilai yang diprediksi jauh dengan nilai diamati standar error mendekati $0,0-1,0$

$$
\mathrm{RMSE}=\frac{0,247032}{6}=0.041172 \text {, }
$$

dimana hasilnya benar karena tidak lebih dari standar error di Tabel 3.

Step 9: Pengembalian hasil output ternormalisasi ke denormalisasi dengan menggunakan nilai-nilai persamaan (8), dimana nilai X adalah $31.189,48$. Berdasarkan hasil tersebut, maka volume pengembangan TPS sampah baru sebesar 31.189,48 kg sehingga dilakukan pengembangan TPS baru dengan melihat nilai range tampungan, sehingga didapatkan pengembangan pengembangan TPST Kawasan di wilayah tersebut.

Hasil perhitungan nilai akurasi menggunakan metode JST dengan algoritma Backpropagation yaitu 7171,02 $\%$.

$$
\begin{aligned}
& \frac{(\text { deviasi absolut })}{(\text { data aktual })}=\text { didapatkan hasil 5521,68 } \\
& \text { MAPE }=\left(\frac{5521,68}{77}\right) * 100=7171,02 \%
\end{aligned}
$$

Uji nilai keakurasian hasil analisis dan data actual menggunakan MAPE adalah 7171,02\% berdasarkan Persamaan (9), dimana $\mathrm{n}$ adalah jumlah data dengan 77 sample.

Menurut tabel nilai perhitungan MAPE, hasil ini masih kurang akurat. Dengan nilai lebih dari 50\%, maka masih banyak ketidaksesuaian hasil yang perlu dikalkulasi. Namun demikian, informasi spasial yang dihasilkan dan ditampilkan melalui format Web-GIS dapat digunakan untuk melakukan analisis dengan pengamatan visual. Tentunya pengamatan ini membutuhkan keahlian dan pengetahuan atas daerah yang cukup tinggi guna memberikan hasil yang baik.

Hasil penelitian ini dapat digunakan sebagai dasar atau menjadi landasan dalam pengambilan keputusan DLKH guna pengembangan lokasi TPST dan TPST Kawasan dengan cakupan informasi pada level kelurahan atau desa.

\section{Kesimpulan}

Hasil pengujian untuk klasifikasi pengembangan TPS sampah menggunakan metode JST dengan algoritma Backpropagation yaitu menghitung tingkat keberhasilan dari perhitungan hasil Analisis spasial dengan data actual. Studi kasus penelitian yang di analisis 77 Desa yang memiliki TPST dan TPST Kawasan. Hasil perbandingan data tersebut digunakan untuk menilai akurasi dari metode yang digunakan berdasarkan MAPE. Hasil menunjukkan persentase metode Jaringan Syaraf Tiruan algoritma Backpropagation hasil dari perhitungan MAPE dengan nilai 7171,02\%, artinya masih kurang akurat karena masih lebih besar dari $50 \%$.

Hasil penelitian ini sudah mampu memberikan gambaran pada pengambil kebijakan untuk pengembangan TPS baru dengan tetap melihat perbandingan hasil dari kajian metode lainnya.

Perlu adanya penelitian lanjutan dengan menggunakan metode lainnya seperti menggunakan JST yang ditingkatkan kemampuannya dengan menggunakan learning vector quantization (LVQ) yang mendukung dengan penggunaan parameter dan adanya penambahan parameter baru dalam pengujiannya. Learning vector quantization (LVQ), dinyatakan bahwa LVQ dapat diterima dengan baik untuk pemodelan data spasial [19].

\section{Daftar Rujukan}

[1] A. M. Menteri Hukum dan Hak Asasi Manusia Republik Indonesia, Undang-Undang Republik Indonesia Nomor 18 Tahun 2008. Jakarta, 2008.

[2] M. S. Drs. Dwi Atmoko Sektiawan, MT; Anjarwati, S.Si, M.Env.; Asri Cahaya Hati, ST; Dian Angelia Sari, ST.; Mufnaiti Prihartini, ST, MT.; Lintang Suska H., S.Si.; Arif Palupi Sandy, ST, MT,; Fery Indarto, ST.; Dian Tristi Agustini, ST.; Desy Gigih Pr, Dokumen Informasi Kinerja Pengelolaan Lingkungan Hidup Daerah Provinsi Jawatimur Tahun 2017. Surabaya: Dinas Lingkungan Hidup Provinsi Jawa Timur, 2017.

[3] K. H. Darmawani, Ferry Sobatnu, Henyningtyas Suhel, "ESTIMASI VOLUME SAMPAH DOMESTIK DI KOTA Banjarmasin Menggunakan Sistem Informasi Geografis (Studi Kasus : Kecamatan Banjarmasin Selatan)," J. Positif, vol. 3, no. 2, pp. 88-92, 2017.

[4] G. P. M. Spagnuolo, Heterogenous Spatial Data: Fusion, Modeling, and Analysis for GIS Applications. Morgan \& Claypool, 2016.

[5] H. J. Miller and E. A. Wentz, "Representation and spatial analysis in geographic information systems," Ann. Assoc. Am. Geogr., vol. 93, no. 3, pp. 574-594, 2003.

[6] M. G. Delgado and J. B. Sendra, "Sensitivity analysis in multicriteria spatial decision-making: A review," Hum. Ecol. Risk Assess., vol. 10, no. 6, pp. 1173-1187, 2004.

[7] K. A. dos S. Diogo Appel Colvero, Ana Paula Duarte Gomes, Luís António da Cruz Tarelho, Manuel Arlindo Amador de Matos, "Use of a geographic information system to find areas for locating of municipal solid waste management facilities," Waste Manag., vol. 77, pp. 1-16, 2018.

[8] R. S. M. L. Melinda Kimberley Pattisina, Linda Tondobala, "Analisis Pemilihan Lokasi Tempat Pembuangan Akhir (Tpa) Berbasis Geography Information System," J. Spasial, vol. 5, 
no. 3, pp. 449-460, 2018.

[9] S. N. Seyed Mohammad Hassan Erfania, Shahnaz Danesha, Seyed Mohsen Karrabia, Mohammad Gheibia, "Statistical analysis of effective variables on the performance of waste storage service using geographical information system and response surface methodology," J. Environ. Manage., vol. 235, no. December 2018, pp. 453-462, 2019.

[10] M. A. F. Amin Farahbakhsh, "Sustainable location and route planning with GIS for waste sorting centers, case study: Kerman, Iran," Waste Manag. Res., vol. 37, no. 3, pp. 287-300, 2019.

[11] B. T. S. Ercument Aksoy, "Geographical information systems (GIS) and Multi-Criteria Decision Analysis (MCDA) integration for sustainable landfill site selection considering dynamic data source," Bull. Eng. Geol. Environ., vol. 78, no. 2, pp. 779-791, 2019.

[12] D. L. H. dan K. K. Sidoarjo, Data Utama dan Data Tambahan Dokumen Informasi Kinerja Pengelolaan Lingkungan Hidup Daerah Kabupaten Sidoarjo 2018. Sidoarjo: Dinas Lingkungan Hidup Daerah Sidoarjo.

[13] A. Vitianingsih, A. Choiron, D. Cahyono, A. Umam, and S. Suyanto, "Spatial Data Modeling on GIS for Classification of Measles-prone Region Using Multiple Attribute Decision Making," Int. J. Intell. Eng. Syst., vol. 12, no. 3, pp. 97-107, 2019.
[14] Badan Standarisasi Nasional, SNI Nomor 03 - 1733 - 2004 Tentang Tata Cara Perencanaan Lingkungan Perumahan di Perkotaan. Bandung: Badan Standarisasi Nasional, 2004.

[15] M. E. S. Dr. Ir. Danis Hidayat Sumadilaga, Pedoman Teknis Pelaksanaan TPS 3R Tempat Pengolahan Sampah Reduce Reuse - Recycle 2019. Jakarta: Kementerian Pekerjaan Umum dan Perumahan Rakyat, 2019.

[16] M. K. T.Sutojo, S.Si., M. K. Edy Mulyanto, S.Si., and Dr. Vincent Suhartono, KECERDASAN BUATAN. SEMARANG: ANDI Yogyakarta, 2010.

[17] S. Kusumadewi, Artificial Intelligence (Teknik dan Aplikasinya), Pertama. Yogyakarta: GRAHA ILMU, 2003.

[18] R. R. W. Dyah Ayu Irawati, Ariadi Retno Ririd, "Implementasi metode trend moment untuk peramalan penjualan buku tulis," ELTEK, vol. 10, no. 1, pp. 24-32, 2020.

[19] H. R. Pourghasemi, A. Gayen, R. Lasaponara, and J. P. Tiefenbacher, "Application of learning vector quantization and different machine learning techniques to assessing forest fire influence factors and spatial modelling," Environ. Res., vol. 184, no. February, p. 109321, 2020. 